Tusupova A.Z., Dzhamaldinova M.T.

\section{Questions of law-making activity of the President of the Republic of Kazakhstan}

\author{
Тусупова А.Ж., \\ Ажамалдинова М.Т. \\ Қазақстан Республикасы \\ Президентінің заң шығару \\ қызметінің мәселелері
}

Тусупова А.Ж., Ажамалдинова М.Т.

\section{Вопросы правотворческой деятельности Президента Республики Казахстан}

The article gives the legal analysis of the acts adopted by the President of the Republic of Kazakhstan. It also considers historical and contemporary conditions of their adoption, defines the legal nature, the role and place of these acts in the system of sources of constitutional law of the Republic of Kazakhstan. To issue decrees, that is implemented by the head of the state, in accordance with appropriate procedures is considered to be internationally recognized and is not regarded as an undemocratic procedure of rulemaking. Decrees of the President of rulemaking nature fall under the general definition of the normative legal acts - written decisions of the authorized bodies, acting as a form of establishing, amending or abolishing the rule of law. In this regard, the article determines the normativity of acts of the head of the state since non-normative acts, including non-normative decrees of the President have a by-law character.

Key words: law-making activity, head of the state, decree, order, message, normative legal acts, by-law, sources of a constitutional law.

Мақалада Қазақстан Республикасы Презилентінің заң шығару қызметінің мәселелеріне құқықтық сараптама жүргізіледі. Мемлекет басшысымен қабылданатын актілерге салыстырмалы құқықтық сипаттама беріледі, оларды қабылдаудың тарихи және заманауи шарттары зерттеледі. Қазақстан Республикасы Президентінің нормативтік құқықтық актілерінің құқықтық табиғаты, олардың Республикамыздың конституциялық құқығының қайнар көздері жүйесіндегі рөлі мен орны анықталған. Тиісті процедураларға сәйкес Елбасы арқылы қабылданатын актілер халықаралық тәжірибеде кең танылған және заң шығару қызметінде демократияға қайшы процедура болып саналмайды. Нормативті сипаттағы Президент жарлықтары нормативтік құқықтық актілердің жалпы анықтамасына сай келеді. Осыған сәйкес, нормативтік емес актілер, сондай-ақ Президенттің нормативтік емес жарлықтары заңға тәуелді сипатқа ие болғандықтан, мақаяа мемлекет басшысы актілерінің нормативтілігін анықтайды.

Түйін сөздер: заң шығару қызметі, мемлекет басшысы, жарлық, өкім, жолдау, нормативтік-құқықтық актілер, заңға сәйкес акт, конституциялық, құқықтың қайнар көзі.

В статье Аается правовая характеристика актов, принимаемых Президентом Республики Казахстан, изучаются исторические и современные условия их принятия, определяются юридическая природа, роль и место в системе источников конституционного права Республики Казахстан. Издание указов, осуществляемое главой государства с соблюдением соответствующих процедур, считается в международной практике общепризнанным и не рассматривается как недемократическая процедура нормотворчества. Указы Президента нормативного характера подпадают под общее определение нормативных правовых актов - как письменных решений уполномоченных законом органов, служащих формой установления, изменения или отмены норм права, а также формой их выражения. В этой связи в работе определяется нормативность актов главы, т.к. ненормативные акты, в том числе и ненормативные указы Президента, имеют подзаконный характер.

Кмючевые слова: правотворческая деятельность, глава государства, указ, распоряжение, послание, нормативно-правовые акты, подзаконный акт, источники конституционного права. 


\section{QUESTIONS OF LAW- MAKING ACTIVITY OF THE PRESIDENT OF THE REPUBLIC OF KAZAKHSTAN}

World constitutional practice shows, that the fact giving to the head of the state the right of lawmaking is not a sign of nondemocratic system in the country headed by him, but characterizes the need to express his political will in this right.

According to article 45 of the Constitution of the Republic of Kazakhstan and article 20 of the Constitutional Law of the Republic of Kazakhstan dated December 26, 1995 № 2733 «On the President of the Republic of Kazakhstan,» The President of the Republic of Kazakhstan shall issue decrees and resolutions which are binding on the entire territory of the country. In the case envisioned by subparagraph 4 of Article 53 of the Constitution the President shall issue laws, and in the case envisioned by subparagraph 2 of Article 61 of the Constitution the President shall issue decrees having the force of laws in the Republic.

If we consider the constitutional experience of some states, for example, the Constitution of India provides that the President has the right to legislate by issuing a decree at the time when the immediate adoption of the law on this subject by parliament is not possible. This means that orders can be issued during breaks in the work of Parliament. The President of Greek may issue acts having legal force by the proposal of the Council of Ministers, but only in cases of emergency. These acts are submitted to Parliament for approval. President of the Republic of Korea has the right to issue decrees having the force of law in cases of economic crisis or threat to national security. The US President constantly uses the authority granted to him to issue decrees («executive orders»). This right, that is not stipulated in the US Constitution, arose on the basis of case law and is mainly used in the federal government

Thus, issuing decrees by the head of the state, in accordance with appropriate procedures is considered to be internationally recognized and is not regarded as a non-democratic procedure of rulemaking.

At the same time, acts issued by the heads of state are not always referred to as «decrees». In a number of countries decrees are issued, which inherently are decrees when compared with the acts of the president, but due to some reasons (e.g. national traditions) are called differently. 
The name of such an act as a «decree» was revived in the former Soviet Union by the Soviet Constitution of 1936.

In the Soviet constitutions the Presidiums as permanent bodies of the Supreme Council had a right to issue decrees having the force of law with the approval of the Supreme Council,

Soviet jurisprudence repeatedly stressed the nature of the decree as a source of law. So, I.N. Kuznetsov wrote: "In general, the legal force of decrees gives way to legal force of law. Laws passed by the Supreme Soviet of the USSR as acts of the supreme representative body of power, does not need approval from any public authority. Decrees, amending and supplementing the Law, on the other hand, are subject to approval by the Supreme Soviet of the USSR at its next session» [1, p. 19-20].

Meanwhile V.O. Luchin emphasized that the legislative decrees are not the same laws, «because the Supreme Council is entitled to take any decision in respect of this decree - to approve it, cancel or make partial changes» $[2$, p. 26].

Such a provision of the decree as a regulation in the legal system of the USSR was stipulated in articles 122-123 of the Constitution of the USSR in 1977 [3, p. 317-319].

In 1990, President of the Soviet Union was granted the right to issue decrees, by making appropriate amendments to the Constitution. However, the Decree of the President of the USSR actually couldn't become a full source of Soviet state law due to the collapse of the country.

In the history of Kazakh national statehood the term « decree of the President» was first used in the Law of the Kazakh SSR from 20.04.1990 «On the establishment of the post of the President of the Kazakh SSR and the amendments the Constitution (the Basic Law) of the Kazakh SSR» [4] .By this act as well as the Law of the Kazakh SSR «On improvement of state power and control structure» amendments were made to the Constitution of the Kazakh SSR, which establishes the legal status of the President of the republic as its highest official and the head of the executive power. [5] This gives ground to speak about the legislative and executiveadministrative nature of the activities of the head of state, who had the right to issue decrees on the basis of and in pursuance of the Constitution and laws of the Kazakh SSR. Decrees of the President can not contradict the Constitution and laws.

During the work of the Supreme Council of the thirteenth convocation President of the Republic of Kazakhstan did not issue decrees having the force of law. However, in March 1995 the Constitutional
Court of the Republic of Kazakhstan found this authority illegitimate, and it posed a question: who is to make laws in this situation? The President of the Republic of Kazakhstan addressed with this question to the Constitutional Court, which declared the Law of RK from 10.12.1993g. «On Temporary Delegation of additional powers to the President the Republic of Kazakhstan and to the heads of local governments» (hereinafter - the Law of 10.12.1993) recovered in connection with the early selfdissolution of the Supreme Council. With the address of the President of the Republic of Kazakhstan the question of legitimacy of the President to issue decrees having the force of constitutional law was regarded by the Constitutional Court of Kazakhstan.

Decrees, that are enacted by the President of the Republic of Kazakhstan, have been and are related to subordinate legal acts. For the first time they acquired the force of the law in accordance with the Law dated 10.12.1993 [6]. It was the first precedent of delegating to the head of the state his legislative functions, anticipating the relevant legal provisions included in the Constitution of the Republic of Kazakhstan in 1995.

Act of 10.12 .1993 is the only normative legal act during the given period, which in fact granted to the President of the Republic of Kazakhstan unlimited powers. In accordance with it the President of the Republic of Kazakhstan issued a total of 136 decrees having the force of law, including the decrees having the force of constitutional law: to amend the Code «On elections in the Republic of Kazakhstan» On Courts and the Status of Judges in the Republic of Kazakhstan and others. Due to them regulatory provision of political and economic reforms in the country is continuously carried out.

The Constitution of 1993 of the Republic of Kazakhstan retained the right of the President to issue decrees and added decisions and orders to presidential normative legal acts (Art. 79). But only the Constitution of 1995 in paragraph 2 of Article 45 establishes the rule according to which the President will be entitled to issue decrees having the force of law, in the case provided for in paragraph 2 of Article 61 of the Constitution: to consider the draft law urgently in view of the fact, that Parliament was to consider the bill within a month, but did not. This decree of the President is valid until Parliament adopts a new law in the manner prescribed by the Constitution.

As the regulatory decree of the President of the Republic of Kazakhstan, containing the constitutional and legal norms is one of the sources of constitutional law, we consider it necessary to 
define its normativity, because non-normative acts, including non-normative decrees of the President have a by-law character. Decrees of the President of a normative nature fall under the general definition of normative legal acts - both the written decisions of the authorized bodies, employees with the form the establishment, amendment or repeal of the law, as well as the form of their expression.

The decree of the President as a regulatory legal act is subject to the requirements of Article 4 of the Constitution, according to which the decree should not contradict the Basic Law. Any decree affecting the scope of the rights and duties of a person and a citizen may not be valid unless it is published. This act shall come into force upon expiration of 10 days after its publication, if it does not fix another term. Non-regulatory Acts of the President shall enter into force from the date of signing, unless otherwise established by the President. Acts of the President, except those, containing state secrets of the Republic or any other secret protected by law shall be published in the official press, established by the Law on normative legal acts of the Republic of Kazakhstan.

If proceed from the generally accepted characteristics of normative legal acts that meet the main objective of normative regulation: ordering of social relations and the introducing uniformity and stability in social life through the establishment of common rules, it should be noted, that some previously adopted decrees of the President had a number of evidences, indicating a non-compliance of the provisions contained therein with a specified purpose. For example:

1) following the entry into force of the relevant laws previously published decrees often needed amendments;

2) in some cases decrees unnecessarily duplicated the provisions of other regulatory legal acts;

3) a significant number of decrees were aimed at settling any specific questions, thereby eliminating the uniformity of common legal rules, and violated the ordering of their legislative regulation.

In addition, the decree of the President is marked by:

1) autonomy (self-regulation) in relation to the whole system of regulatory legal acts of the Republic of Kazakhstan;

2) not infrequently anticipatory regulation of issues relating to managing Parliament of the Republic of Kazakhstan;

3) follow the principle of expediency, not legitimacy: in the preambles of most of these acts it is not indicated, that they are issued on the basis and in pursuance of laws, and it is said, that they are issued on the basis of a particular purpose or in accordance with other decrees;

4) freedom from any restrictions in the legal regulation, carried out exclusively at the discretion of the head of the state, which leads to a diminution of constitutionally established legislative regulation of social relations, as well as values of law.

We also emphasize, that the regulatory decrees may simultaneously contain non-regulatory (operational and administrative) provisions, that do not detract from their overall regulatory nature. The main purpose of the regulatory decrees was to ensure continuity of the legal regulation of social relations in the transition period.

The practice of issuing decrees of the President due to the desire as quickly as possible to change the foundations and the tendencies of the social order inherent in Soviet society, shows the deformation ratio between the given normative legal acts and other types of them. Since 1993, this fact has been emphasized in most decrees with legal content.

However, a number of positive results of this rulemaking should be noted. The adoption of decrees allowed more quickly resolve urgent problems of social development, contributed to the development of legal relations in different social spheres.

The dominant position of the decree of the President of the Republic of Kazakhstan in the transition period as a source of constitutional law was due to several factors. The main among them, from our point of view is incomplete performance of the principle of separation of powers between the President of the Republic of Kazakhstan and other state bodies, as manifested in the activities of almost all branches of government. The legislative (representative) power represented by the Supreme Council first granted the President the right to issue decrees on a wide range of issues, and then was underactively engaged in lawmaking.

The executive power in accordance with the Constitution of the Republic of Kazakhstan of 1993 was headed by the President of the Republic of Kazakhstan, and after the adoption of the Constitution of the Republic of Kazakhstan in 1995 continued to focus on his orders, as the President had the right to appoint and dismiss the Prime Minister of the Republic of Kazakhstan and the ministers and to take a decision on the resignation of the Government. The Constitutional Council of the Republic of Kazakhstan following the adoption of the Constitution of the Republic of Kazakhstan in 1995, found all decrees adopted earlier corresponding to the Basic Law. 
The decree of the President of the Republic of Kazakhstan having the force of law, has the same legal force as a law; its nature is not restricted to any subject of regulation or in action. But as it is issued by not a legislative body its procedure is different from the one for the adoption of the law by the Parliament (it should be stressed, that this procedure has not been established regulatory), according to legal significance the law, issued by the President, can only be equal to a law adopted traditionally. It is also difficult to consider it as an act of delegated legislation. To avoid confusion on the status of the law, it is advisable to leave the name of the act, issued by the president with legislative powers delegated to him, «the decree having the force of law.» The Constitution of the Republic of Kazakhstan itself must contain the answers to the questions about the legal nature of the law, issued by the President. Nevertheless, the basic legal act and, consequently, a source of constitutional law in Kazakhstan, should be, besides the Constitution, not the decree but the law.

Orders of the President of the Republic of Kazakhstan are issued on the basis and in pursuance of the Constitution, laws and decrees of the President. Administrative and regulatory issues are settled by the orders of the President of the Republic, in accordance with the competence of the President of the Republic the persons, who do not have constitutional status shall be appointed and dismissed. Where necessary, the President of the Republic in the exercise of its powers can independently determine in what form of the act he will carry out his powers: the decree or order» $[7$, p. 267].
In accordance with paragraph 1 of Article 44 of the Constitution of the Republic of Kazakhstan of 1995 the President of the Republic of Kazakh makes his annual oral or written Address to the people of Kazakhstan on the situation in the country and the main directions of domestic and foreign policy of Kazakhstan.

President's Addresses are programmatic in nature and are of great political significance, since it contains important political and legal initiatives of the President. However, this is no reason to consider them as regulations or to assume, that they have the highest legal force, because they are not constitutional acts. Address of the President is not a normative legal act of a binding character, since there are no legal provisions.

In conclusion we cite an opinion of Machiavelli from his work «Sovereign»: «The law is directly linked to the political will of the state and the legislator, and is derived from the balance of forces in the political sphere, from the dominant political force» [8, p. 50]. The significance of lawmaking activity of the President of the Republic of Kazakhstan is that the constitutional powers of the President requiring a publication act of the head of the state are carried out by the above-mentioned acts; issues are solved concerning the ensuring of the coordinated functioning of all branches of government established by the Constitution; the legal regulation of issues that are not within the legislative competence of the Parliament, as well as those, that do not relate to established laws of the competence of the Government and other public bodies; decisions are taken on strategic issues of economic and socio-political development of the Republic of Kazakhstan.

\section{References}

1 Kuznetsov I.N.-The competence of the higher authorities of the USSR. - M.: the Legal literature, 1969. $-246 \mathrm{p}$.

2 Luchin V.O. Sources of Soviet state law. - Kuibyshev, 1976. - 160 p.

3 Constitution of the USSR: Political and legal comment. /Ed. B.N Ponomarev edition - M.: Politizdat, 1982. - 398 p.

4 Law of the Kazakh Soviet Socialist Republic dated April 24, 1990 «On the establishment of the post of President of the Kazakh Soviet Socialist Republic and the Amendments to the Constitution(Fundamental Law) of Kazakh SSR» // Bulletin of the Supreme Soviet of the Kazakh SSR, 1990., №18, Art. 190

5 Law of the Kazakh Soviet Socialist Republic from November 20, 1990 № 334-XII «On improving the structure of state power and control in the Kazakh Soviet Socialist Republic and the Amendments to the Constitution (Fundamental Law) of Kazakh SSR» // Bulletin of the Supreme Council of the Kazakh SSR, 1990, № 47, Art. 413

6 Lawof the Republic of Kazakhstan on December 10, 1993 №2576-HII «On Temporary Delegation of the Presidentof the Republic ofKazakhstanandthe heads oflocal governmentsadditional powers» - List of Supreme Council of the Republic of Kazakhstan», 1993, № 23-24, Art.51

7 The Constitution of the Republic of Kazakhstan: scientific and legalcomments/ Ed. G.S. Sapargalieva. - Almaty: Jetijargy, 2004. $-584 \mathrm{p}$.

8 Machiavelli N. The Prince /Translated from IT. - Almaty: GSW «Adilet», 2001. - 224 p. 
Естественное право имеет силу Аля всего человечества.

Аатинское изречение 